\title{
Asymmetrical Linkages between Foreign Exchange and Stock Markets: Empirical Evidence through Linear and Non-Linear ARDL
}

\author{
Rabia Luqman ${ }^{1,2, *(1)}$ and Rehana Kouser ${ }^{2}$ \\ 1 Department of Management Sciences, COMSATS Vehari Campus, Vehari 61100, Pakistan \\ 2 Department of Commerce, Bahauddin Zakariya University, Multan 66000, Pakistan; \\ rehanakousar@bzu.edu.pk \\ * Correspondence: rabia@ciitvehari.edu.pk
}

Received: 27 June 2018; Accepted: 20 August 2018; Published: 24 August 2018

\begin{abstract}
The symmetrical relationship between currency and equity markets has gained much attention among academicians and policy makers in the recent era. Many studies conducted on this relationship have concluded that there is short-run relationship between these variables and found less evidence about a long-run relationship. Moreover, all previous studies supposed the linear or symmetrical relationship between these variables. In this study, we use daily time series data from G8+5 countries and Pakistan for 2000-2016 and apply linear and non-linear autoregressive distributed lag (ARDL) to check the symmetrical and asymmetrical relationship between currency and equity markets. Results have shown that there are asymmetrical linkages between the currency and equity markets.
\end{abstract}

Keywords: asymmetric linkages; linear and non-linear autoregressive distributed lag (ARDL); currency and equity markets; volatility

\section{Introduction}

Are currency and equity markets interrelated? If these markets are interdependent then what kind of relationship do they have? Are these markets linearly or non-linearly related? All these questions have gained substantial consideration with the development of money and asset markets, increased flexibility in currency market policies, and recreation of foreign exchange policies. To test the relationship between currency and equity market, there are two theoretical approaches. According to asset approach by Branson (1983) and Frankel (1983), stock price is one of the main determinants of exchange rate. If there is increase in the stock price, it will lead to an increase in the wealth of the country. This will lead to increasing demand for domestic currency and currency will appreciate as a result. According to flow approach by Dornbusch et al. (1980), exchange rate leads stock prices. But if domestic currency depreciates, it will increase the profits of export firms. If profits of the export-oriented firms are high, this can lead to the increase in the stock prices of firms. But at the same time, it will lead to an increase in the cost of imported goods, so if firms are not export-oriented they suffer losses in the form of high production costs due to currency depreciation. If costs are rising, profits will be lower and in turn stock prices will decline. So, one can conclude that stock prices can move each way. The first approach is based on the expectations of investors, if they expect that the company is going to be in profit they invest more and this would result in appreciation of currency. The second approach is based on the wealth effect if domestic currency appreciates or depreciates, which will change the stock price. 


\section{Literature Review}

The first study on the relation of stock price and exchange rate was conducted by Aggarwal (1981) and concluded that these variables had a positive relationship. According to Solnik (1987) there is no statistical relationship among the variations of stock price and exchange rates. By contrast, Soenen and Hennigar (1988) concluded that these variables had a strong negative relationship. Jorion (1990) established a connection between exchange rate and stock prices. Another study conducted by Ma and Kao (1990) explained the different factors of a country as imports and exports strengthen a country and the nature of economies. Bahmani-Oskooee and Sohrabian (1992) tested the relationship of these variables and found the positive relationship between these two. Most of the empirical studies at the outset ignore the fact that variables are not stationary. This study checked the integration and causality among the variables and reported the bi-directional causality among the variables in the short run. Many other researchers also studied the causality among these variables and showed the uni and bi-directional causality among different countries, such as Mookerjee and Yu (1997) for Hong Kong, Tokyo and Singapore and Abdalla and Murinde (1997) for four Asian countries. Other studies also conducted on this relationship supported the results, such as Granger et al. (2000); Smyth and Nandha (2003); Phylaktis and Ravazzolo (2005); Obben et al. (2006); Yau and Nieh (2006); Pan et al. (2007); Ismail and Isa (2009); Rahman and Uddin (2009); Kutty (2010); Zhao (2010); Alagidede et al. (2011); Lean et al. (2011); Lee et al. (2011); Eita (2012); Inegbedion (2012); Kollias et al. (2012); Tsai (2012); Wickremasinghe (2012); Buberkoku (2013); Khan et al. (2013); Boonyanam (2014); Caporale et al. (2014); Moore and Wang (2014) and Yang et al. (2014). All these studies did not find a long-term relationship among the variables but there are studies that reported a long-term relationship between these two variables, such as Richards and Evans (2009); Yau and Nieh (2009); Tian and Ma (2010); Chortareas et al. (2011); Harjito and McGowan (2011); Parsva and Lean (2011) and Lin (2012). Groenewold and Paterson (2013); Tsagkanos and Siriopoulos (2013); Unlu (2013); and Tuncer and Turaboglu (2014).

Bahmani-Oskooee and Saha (2015) reviewed all the studies on the relationship of currency and equity markets and proposed a new method to estimate the relation. All research had the same assumption that currency market changes had symmetrical effect on the equity market. Shin et al. (2014) apply the non-linear autoregressive distributed lag (NARDL) method to check the short- and long-run asymmetrical effects of exchange rates and stock prices. Bahmani-Oskooee and Saha (2015) studied the asymmetrical effects by using the US data as sample and suggested applying this to other countries. Bahmani-Oskooee and Saha (2016) applied the same bivariate model for the nine countries to check the both symmetrical and asymmetrical effects between the equity market and currency markets. Bahmani-Oskooee and Saha (2017) apply the non-linear ARDL to check the asymmetries between the exchange rate and stock price by using the monthly data for 24 countries included in the sample. The main objective is to check the long-term and short-run relationships and the symmetrical and asymmetrical effects between these two variables; simple linear ARDL is applied for the symmetrical effect and non-linear ARDL is applied for checking the asymmetrical effect. The sample countries for this study are G-8 Countries (Canada, France, Germany, Italy, Japan, UK, USA and Russia), five emerging economies (Brazil, China, India, Mexico and South Africa), and Pakistan. There has been no study conducted for daily data using these countries for the 2000-2016-time period.

\section{The Models and Methods}

To check the long-run relationship between the stock price indices and real exchange rate, the following equation is used as given by Bahmani-Oskooee and Sohrabian (1992):

$$
\operatorname{LnSP}_{\mathrm{t}}=\alpha+\beta \operatorname{LnEX}_{\mathrm{t}}+\varepsilon_{\mathrm{t}}
$$


In this equation SP denotes the stock price index for each country and EX denotes the exchange rate for each country. The relationship between exchange rates and stock prices can be either positive or negative depending on whether the firm is export-oriented or import-oriented. An export-orientated firm will benefit from depreciation of the home currency as depreciation makes exports cheaper. This will lead to an increase in competitiveness and increase in earnings of the firm, hence, stock prices will increase (a positive relationship). Whereas an import-oriented firm is hurt by depreciation of the home currency as the cost of imported inputs is increased as a result of depreciation of home currency. This will lead to a decline in profitability, and thus stock prices will decrease (a negative relationship).

$\beta$ slope coefficient will be statistically significant if residuals of Equation (1) are stationary at order less than the variables given in the equation. If variables are stationary at order 1 then residuals must be stationary at a level that also indicates that there is long-term integration between the variables of Engle and Granger (1987). To check the short-run integration, an error correction model can be applied as follows:

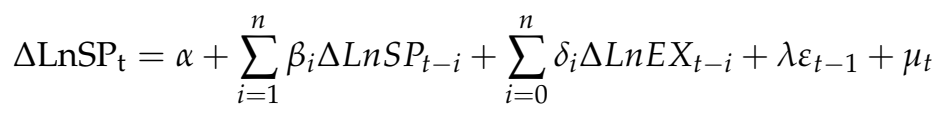

By Equation (1), we can obtain the error correction variable; the slope of the ECM must be negative and significant to confirm that there is short-run relationship between the variables. That also indicates the speed of adjustment towards the long-run relationship of Banerjee et al. (1998).

\subsection{Linear Auto Regressive Distributed Lag Model (ARDL)}

When the order of integration is not same of all variables then we use the lagged variables as proposed by Pesaran et al. (2001):

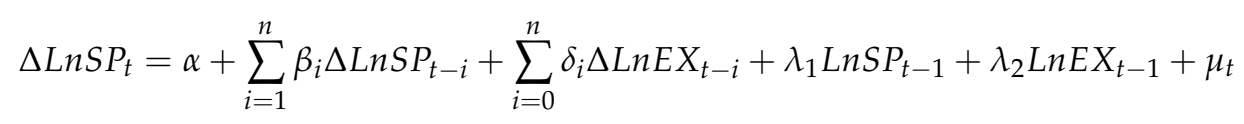

The F-test is used to check the joint significance of all variables included in the Equation (3). By this equation, both short-run and long-run effects between the variables can be measured.

\subsection{Non-Linear Auto Regressive Distributed Lag Model (NARDL)}

To check the asymmetries, we have to make a separate series for appreciation and depreciation as proposed by Bahmani-Oskooee and Saha $(2015,2016)$. A series of exchange rate will be divided in its positive movements or appreciation, as indicated by $\mathrm{POS}^{\wedge} \mathrm{EX}$, and negative movements or depreciation, as indicated by $\mathrm{NEG}^{\wedge} \mathrm{EX}$, and is given as follows:

$$
\begin{gathered}
\operatorname{POS}_{t}^{E X}=\sum_{j=1}^{t} \Delta \operatorname{LnEX_{j}^{+}}=\sum_{j=1}^{t} \max \left(\Delta \operatorname{LnEX_{j},0)}\right. \\
N E G_{t}^{E X}=\sum_{j=1}^{t} \Delta \operatorname{LnEX_{j}^{-}}=\sum_{j=1}^{t} \min \left(\Delta \operatorname{LnEX_{j},0)}\right.
\end{gathered}
$$

To check the impact of positive and negative movements of one variable on the other variable, Equation (3) will be transformed as:

$$
\begin{aligned}
\Delta L n S P_{t}=\alpha+ & \sum_{i=1}^{n} \beta_{i} \Delta L n S P_{t-i} \\
& +\sum_{i=0}^{n} \delta_{i}^{1} \Delta P O S_{t-i}^{E X} \\
& +\sum_{i=0}^{n} \delta_{i}^{2} \Delta N E G_{t-i}^{E X}+\lambda_{1} L n S P_{t-1}+\lambda_{2} P^{n} O S_{t-1}^{E X}+\lambda_{3} N E G_{t-1}^{E X}+\mu_{t}
\end{aligned}
$$


Due to the nature of variables of $P O S^{E X}$ and $N E G^{E X}$, the linear ARDL model is now converted into the non-linear ARDL. By using this model, we can check the asymmetries as positive and negative changes that have same effect or a different impact on stock prices according to Shin et al. (2014). If the estimated values of positive and negative coefficients of the exchange rate have the same numerical value and the same sign (either both positive or both negative) then it can be concluded that exchange rate changes have symmetrical short-run effects on stock prices. The long-run effects are interpreted from the estimates of the coefficients of the lagged level values. The symmetrical or asymmetrical long-run effects of changes in exchange rates on stock prices are given by lamda two and lamda three. We can change the dependent variable to check the asymmetrical impact of stock prices on exchange rates. The linear ARDL and the non-linear ARDL model can be described as follows:

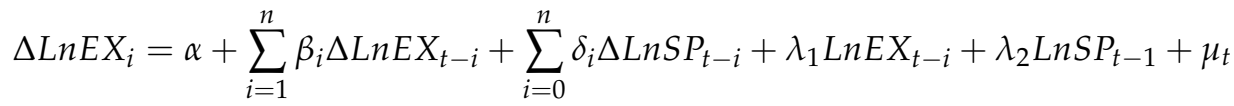

$$
\begin{aligned}
& \Delta L N E X_{t}=\alpha+\sum_{i=1}^{n} B_{i} \Delta L N E X_{t-i}+\sum_{i=0}^{n} \delta_{i}^{1} \Delta P O S_{t-i}^{S P}+\sum_{i=0}^{n} \delta_{i}^{2} \Delta N E G_{t-i}^{S P}+\lambda_{1} L n E X_{t-1} \\
& +\lambda_{2} P O S_{t-1}^{S P}+\lambda_{3} N E G_{t-1}^{S P}+\mu_{t}
\end{aligned}
$$

In these equations, a series of stock price is divided in partial sums of positive and negative changes. They are created by using the same formula as used by Equation (4). Error-correction models (3) and (5) as well as (6) and (7) are estimated in the next section for each of the 24 countries in our sample.

\section{Empirical Results}

The results for this study are comprised from the daily data of stock indices and real exchange rate for 14 countries includes Canada, France, Germany, Italy, Japan, UK, USA, Russia, Brazil, China, India, Mexico and South Africa and Pakistan. There is no study conducted for daily data using these countries for the 2000-2016-time period. Stationary tests are conducted based on the Dickey and Fuller (1979) and Phillips and Perron (1988) tests. The results have shown that all the stock indices for sample countries are non-stationary at level but stationary at 1st difference. Exchange rates for all the countries are also stationary at 1st difference but non-stationary at level.

In Table 1, long-run estimates for stock indices and exchange rates are given and show that the stock indices of Canada, France, Germany, Italy, Japan, UK, USA, Russia, Brazil, China, India, Mexico, South Africa and Pakistan have a long-term statistically significant relationship with the real exchange rate of all these countries. The stock indices of Brazil, China, Canada, France, Italy, UK and USA have negative significant relationship and all other counties have the positive statistically significant relationship.

In Table 2, a vector error correction model (VECM) is applied to check the short-run relationship between the stock indices and real exchange rate. ECM shows the speed of adjustment and it is negative and statistically significant in all the countries, showing that these two variables have a short-run relationship and there is cointegration between these two variables. To check the symmetrical and short-run relationship, ARDL is applied.

In Table 3, stock indices are taken as dependent variable and results show that stock indices depend on its lagged terms and also have a short-run relationship with exchange rates in all the sample countries.

In Table 4, exchange rates are taken as dependent variable and show that exchange rate can also be predicted by its lagged term. If exchange rate changes that will also lead towards the change in stock price in short run. CUMSUM graphs are given in the Appendix A that shows the stability of variables.

In Table 5, results are shown from the non-linear ARDL estimation, first taking the stock price as the dependent variable, and asymmetrical changes in exchange rate are observed by taking negative and positive series for all sample countries. The Wald test is applied to check the asymmetrical impact 
of the exchange rate on stock prices. The results show that there is asymmetrical impact on stock prices by positive and negative changes in the stock prices. The short-run asymmetrical impact of exchange rate changes on stock prices are significant among all the countries, Canada, France, Germany, Italy, Japan, UK, USA, Russia, Brazil, China, India, Mexico and South Africa and Pakistan at different lag orders. Wald test results show that positive and negative coefficients have a different impact on stock prices in all sample countries.

In Table 6, results are shown from the non-linear ARDL estimation, taking the exchange rate as dependent variable, and asymmetrical changes in stock prices are observed by taking negative and positive series for all sample countries. The Wald test is applied to check the asymmetrical impact of stock prices on exchange rates. Results show that there is an asymmetrical impact on exchange rates by positive and negative changes in stock prices. The short-run asymmetrical impact of stock price changes on exchange rates are significant among all the countries Canada, France, Germany, Italy, Japan, UK, USA, Russia, Brazil, China, India, Mexico and South Africa and Pakistan at different lag orders. Wald test results show that positive and negative coefficients have a different impact on exchange rates in all the sample countries.

Table 1. Long-run estimates.

\begin{tabular}{|c|c|c|c|c|c|c|c|}
\hline & Brazil & China & India & Mexico & South Africa & Pakistan & Canada \\
\hline ER & $-14,619.46^{* * * *}$ & $-626.109^{* * *}$ & $749.024^{* * *}$ & $2106.868^{* * *}$ & $0.362 * * *$ & $686.057^{* *}$ & $-9628.912^{* * *}$ \\
\hline CONSTANT & $5033.804 *$ & $41,765.05$ * & $2273.734^{*}$ & $5914.022 *$ & $15,838.97$ * & 392.030 * & 6073.705 * \\
\hline ER & $1353.288^{* * *}$ & $-13,608.03^{* * *}$ & $101.587^{* * *}$ & $-177.187^{* * *}$ & $-40.529 * * *$ & $24.327^{* * *}$ & $-1461.909^{* * *}$ \\
\hline
\end{tabular}

Table 2. Vector error correction method.

\begin{tabular}{cccccccc}
\hline & Brazil & China & India & Mexico & South Africa & Pakistan & Canada \\
\hline CONSTANT & $11.980^{*}$ & $0.404^{*}$ & $5.043^{*}$ & $4.344^{*}$ & $-0.096^{*}$ & $10.213^{*}$ & $1.559^{*}$ \\
ECM(-1) & $-0.006^{* * *}$ & $-0.001^{* * *}$ & $-0.003^{* * *}$ & $-0.003^{* * *}$ & $-0.368^{* * *}$ & $-0.001^{* * *}$ & $-0.002^{* * *}$ \\
\hline & Germany & Italy & Japan & UK & USA & Russia & France \\
\hline CONSTANT & $0.847^{*}$ & $-5.592^{*}$ & $0.049^{*}$ & $5914.544^{*}$ & $1.931^{*}$ & $0.409^{*}$ & $0.847^{*}$ \\
ECM(-1) & $-0.004^{* * *}$ & $-0.001^{* *}$ & $-0.001^{* * *}$ & $-0.997^{* * *}$ & $-0.001^{* * *}$ & $-0.001^{* * *}$ & $-0.004^{* * *}$ \\
\hline
\end{tabular}

$10 \%$ level is identified by ${ }^{*}$ and at the $5 \%$ level by ${ }^{* *}$ and $1 \%$ by ${ }^{* * *}$. 
Table 3. Autoregressive distributed lag (ARDL) dependent variable: stock price.

\begin{tabular}{|c|c|c|c|c|c|c|c|c|c|c|c|c|c|c|}
\hline Variables & Brazil & China & India & Mexico & South Africa & Pakistan & Canada & France & Germany & Italy & Japan & UK & USA & Russia \\
\hline $\mathrm{SP}(-1)$ & $0.946 *$ & $1.049 *$ & $1.051 *$ & $1.182 *$ & $0.712 *$ & $0.990 *$ & $0.946 *$ & $0.959 *$ & $1.003 *$ & $0.968 *$ & $0.966 *$ & $0.961 *$ & $0.925 *$ & $1.017 *$ \\
\hline $\mathrm{SP}(-2)$ & $0.052 *$ & $-0.105^{*}$ & -0.066 * & -0.294 * & -0.170 * & $0.013 *$ & $0.052 * *$ & $0.005 *$ & $-0.006^{* *}$ & $0.029 *$ & $0.028 *$ & $-0.014 *$ & $0.042 *$ & $-0.022 *$ \\
\hline $\mathrm{SP}(-3)$ & -0.050 * & 0.108 * & $0.004 *$ & $-0.002 *$ & $0.225 *$ & $0.019 *$ & -0.050 * & -0.013 * & $0.018 *$ & & $-0.022 *$ & $0.003 *$ & $0.045^{*}$ & -0.003 \\
\hline $\mathrm{SP}(-4)$ & 0.051 & -0.053 & $0.009 *$ & 0.111 & -0.241 & $-0.025 *$ & 0.051 & 0.045 & -0.007 * & & 0.025 & 0.047 & -0.0124 * & 0.006 \\
\hline ER & $-516.217^{*}$ & 73.850 * & 9.688 & $78.586^{* *}$ & $38.878^{*}$ & $-0.289^{* *}$ & $-5168.217^{*}$ & $631.730 * *$ & $5.043 *$ & $15.363^{* *}$ & $0.140^{* *}$ & $575.917^{* *}$ & $-19.730 * *$ & $-0.175^{*}$ \\
\hline $\mathrm{ER}(-1)$ & $548.354 * *$ & $2.334 * *$ & $19.115^{* *}$ & $-122.58^{* *}$ & $-11.080^{* * *}$ & $-0.099^{* *}$ & $5438.354^{* *}$ & $-562.986 *$ & $53.295 *$ & & 10.300 * & $-691.94^{*}$ & $20.837^{*}$ & $-0.363^{* *}$ \\
\hline $\mathrm{ER}(-2)$ & $-989.918 *$ & $4.565^{* *}$ & $28.669^{* *}$ & -71.507 * & 101.351 & $9.116 * *$ & $-989.918 *$ & $-134.382^{* *}$ & $-51.912 *$ & & $-12.135^{* *}$ & $101.143^{* *}$ & $-4.178^{*}$ & 0.968 ** \\
\hline ER(-3) & $440.491 * *$ & -85.540 & -32.728 & $100.816^{*}$ & -75.525 & -7.272 & $440.491 *$ & 62.125 & -168.796 & & $8.275^{*}$ & -21.625 & 0.739 & 1.597 \\
\hline ER(-4) & 299.660 & $38.719 *$ & 13.831 & $18.969 *$ & 36.783 & 0.124 * & 299.661 & 3.873 & 171.858 * & & -6.591 & $34.641 *$ & 2.215 & -1.981 * \\
\hline C & $-11.972 *$ & $10.048^{* *}$ & -6.707 & 98.138 * & 239.51 * & $-85.220 * *$ & -11.975 * & 7.903 * & $-7.447^{* *}$ & $10.572 *$ & $18.742^{* *}$ & $14.433^{* *}$ & $12.212^{* *}$ & $0.640 *$ \\
\hline R Square & 0.998 & 0.997 & 0.999 & 0.996 & 0.441 & 0.999 & 0.998 & 0.995 & 0.998 & 0.998 & 0.996 & 0.991 & 0.998 & 0.998 \\
\hline F Stats & $35,3270.2$ & 188.4 & 806.1 & 135.9 & 387.24 & 556.7 & 350.2 & 1164.7 & 2856.9 & 7731.8 & $162,306.3$ & $95,887.73$ & $27,131.6$ & $320,609.2$ \\
\hline F (Prob) & 0.000 & 0.000 & 0.000 & 0.000 & 0.000 & 0.000 & 0.000 & 0.000 & 0.000 & 0.000 & 0.000 & 0.000 & 0.000 & 0.000 \\
\hline
\end{tabular}

Table 4. ARDL dependent variable: exchange rate.

\begin{tabular}{|c|c|c|c|c|c|c|c|c|c|c|c|c|c|c|}
\hline Variables & Brazil & China & India & Mexico & South Africa & Pakistan & Canada & France & Germany & Italy & Japan & UK & USA & Russia \\
\hline $\begin{array}{c}\mathrm{SP} \\
\mathrm{SP}(-1) \\
\mathrm{SP}(-2)\end{array}$ & $\begin{array}{c}-6.7 \times 10^{-6 *} \\
2.5 \times 10^{-6 *} \\
4.217 \times 10^{-6 *}\end{array}$ & $-3.6 \times 10^{-7 *}$ & $\begin{array}{c}1.31 \times 10^{-5 *} \\
-4.2^{* *} \\
6.367 \times 10^{-6 *}\end{array}$ & $1.617 \times 10^{-6 * *}$ & $-1.107 \times 10^{-6 *}$ & $2.897 \times 10^{-7 *}$ & $1.06 \times 10^{-7 *}$ & $\begin{array}{c}1.02 \times 10^{-5 * * *} \\
-1.04 \times 10^{-5 * * *}\end{array}$ & $-5.99 \times 10^{-8 * * *}$ & $-7.24 \times 10^{-9} * *$ & $7.11 \times 10^{-6 * *}$ & $\begin{array}{c}1.33 \times 10^{-5 * *} \\
-1.34 \times 10^{-5} \text { ** }\end{array}$ & $\begin{array}{c}-0.000267^{*} \\
-8.43 \times 10^{-5} \text { ** } \\
0.003 *\end{array}$ & $5.78 \times 10^{-6 * *}$ \\
\hline $\mathrm{SP}(-3)$ & & & $-3.33 \times 10^{-6 *}$ & & & & & & & & & & & \\
\hline $\mathrm{ER}(-1)$ & $1.075^{* *}$ & $0.927 * *$ & $0.962 * *$ & $0.943 * * *$ & $0.966^{*}$ & 0.481 * & 0.870 * & 0.998 * & 0.990 * & 0.998 * & 0.792 * & $1.034 *$ & 0.999 * & $0.949 *$ \\
\hline $\mathrm{ER}(-2)$ & -0.097 * & 0.098 * & -0.046 & 0.023 & -0.015 * & 0.154 & 0.129 * & & & & 0.149 * & -0.041 & & $-0.007 *$ \\
\hline $\operatorname{ER}(-3)$ & $0.093 *$ & & $0.083^{*}$ & $0.0327 *$ & 0.018 & 0.205 * & & & & & 0.055 & $-0.022^{*}$ & & $0.015 *$ \\
\hline $\mathrm{ER}(-4)$ & & -0.100 * & & & $0.026^{*}$ & 0.158 * & & & & & & $0.029 *$ & & 0.041 \\
\hline & $0.0015 *$ & $0.003 * *$ & 0.024 * & -0.001 * & 0.058 * & 0.036 * & -0.001 * & $0.002 *$ & 0.001 * & 0.001 * & 0.100 * & $0.002 *$ & $0.007 *$ & $0.007 *$ \\
\hline R Square & 0.997 & 0.9 & 0. & 0. & 0.997 & 0.9 & 0. & 0. & 0. & 0. & 0.9 & 0.9 & 0. & 0.998 \\
\hline F Stats & $361,934.6$ & $6,563,187$ & $729,431.2$ & $562,696.6$ & $413,609.4$ & 123,025 & $1,010,879$ & 788,714 & $1,175,828$ & 117,554 & $387,782.1$ & $255,209.2$ & $792,247.5$ & $638,360.3$ \\
\hline F (Prob) & 0.000000 & 0.000000 & 0.000000 & 0.000000 & 0.000000 & 0.000000 & 0.000000 & 0.000000 & 0.000000 & 0.000000 & 0.000000 & 0.000000 & 0.000000 & 0.000000 \\
\hline
\end{tabular}

$10 \%$ level is identified by * and at the $5 \%$ level by ** and $1 \%$ by $* * *$. 
Table 5. Non-linear ARDL (NARDL) dependent variable: exchange rate.

\begin{tabular}{|c|c|c|c|c|c|c|c|c|c|c|c|c|c|c|}
\hline Variables & Brazil & China & India & Mexico & South Africa & Pakistan & Canada & France & Germany & Italy & Japan & UK & USA & Russia \\
\hline $\mathrm{dER}(-1)$ & & $-0.076^{*}$ & $-0.033^{*}$ & & $-0.031 *$ & $-0.530^{*}$ & $-0.141 *$ & & & & $-0.205^{*}$ & $0.0346 *$ & & $-0.057 *$ \\
\hline $\mathrm{dER}(-2)$ & & $0.059 *$ & -0.088 * & & -0.049 * & -0.396 * & & & & & -0.050 * & & & -0.058 * \\
\hline $\mathrm{dER}(-3)$ & & $0.094 *$ & 0.024 * & & -0.027 * & -0.203 * & & & & & & -0.026 * & & -0.043 * \\
\hline $\operatorname{dER}(-4)$ & & $0.021 *$ & & & -0.027 & -0.090 * & & & & & & $-0.0 \angle 0$ & & -0.033 * \\
\hline ER(-1) & $-0.004 *$ & $0.002 *$ & $-0.001 *$ & 0.042 * & $-0.008 *$ & $0.087 *$ & $0.003 *$ & $0.0 .47 *$ & -1.50 * & $-0.087 *$ & 0.043 * & $-0.079 *$ & -0.048 * & $-0.007 *$ \\
\hline $\begin{array}{l}\text { ER(-2) } \\
\text { ER(-3) }\end{array}$ & $-0.074 *$ & & & & & & & & $\begin{array}{l}1.74^{*} \\
1.58^{*}\end{array}$ & & & & & \\
\hline ER(-4) & $0.043 *$ & & & & & & 0.05 * & & $-1.89 \times 10^{-15 *}$ & & & & & \\
\hline POS(SP) & $-9.59 \times 10^{-5}$ & $5.6 \times 10^{-5 *}$ & & $6.987^{* *}$ & & & $1.08 \times 10^{-7 * * *}$ & $1.07 \times 10^{-18 * *}$ & $-3.03 \times 10^{-19 * *}$ & & & $1.52 \times 10^{-5 * *}$ & $-0.005^{* *}$ & \\
\hline $\begin{array}{l}\text { POS(SP-1) } \\
\text { PSSSP-2) }\end{array}$ & & $-3.78 \times 10^{-6 *}$ & $-1.16 \times 10^{-6 *}$ & $5.879 * *$ & & $1.03 \times 10^{-6 * *}$ & & $9.28 \times 10^{-19} * *$ & $-3.04 \times 10^{-19 *}$ & $-2.02 \times 10^{-8 *}$ & $0.005 * *$ & $-1.38 \times 10^{-5} * *$ & -0.004 * & $-3.00 \times 10^{-5}$ \\
\hline $\begin{array}{l}\text { POS(SP-2) } \\
\text { POS(SP-3) }\end{array}$ & & $-3.77 \times 10^{-6 *}$ & & & $2.73 \times 10^{-6 *}$ & & & $\begin{array}{c}-5.98 \times 10^{-18} \\
5.36 \times 10^{-18}\end{array}$ & $\begin{array}{l}-2.86 \times 10^{-19 *} \\
-106 \times 10^{-18 *}\end{array}$ & & & $-104 \times 10^{-5 *}$ & 0.087 & \\
\hline POS(SP-4) & & $3.65 \times 10^{-6}$ & & & & & & $-1.38 \times 10^{-18 *}$ & $1.96 \times 10^{-18}$ & & -0.037 & $8.98 \times 10^{-6 *}$ & & \\
\hline NEGSP & $0.006^{* *}$ & & & $1.68^{* *}$ & & & $1.09 \times 10^{-7 *}$ & $-1.17 \times 10^{-18 *}$ & $1.32 \times 10^{-19 *}$ & & & & & \\
\hline NEGSP(-1) & & $-1.99 \times 10^{-6 *}$ & $-4.91 \times 10^{-5 *}$ & $1.12 *$ & $-7.88 \times 10^{-6 *}$ & $1.32 \times 10^{-6 *}$ & & $8.67 \times 10^{-19 *}$ & $-1.05 \times 10^{-18 *}$ & $-1.92 \times 10^{-8 *}$ & $9.80 \times 10^{-5 *}$ & $-1.12 \times 10^{-8 *}$ & $-0.007 *$ & $-3.3 \times 10^{-5}$ * \\
\hline $\begin{array}{l}\text { NEGSP(-2) } \\
\text { NEGSP(-3) }\end{array}$ & $-0.023 *$ & & $\begin{array}{r}9.84 \times 10^{-5 *} * \\
-5.08 \times 10^{-5} *\end{array}$ & & & & & $\begin{array}{l}4.90 \times 10^{-18 *} \\
-881 \times 10^{-18 *}\end{array}$ & $\begin{array}{c}3.26 \times 10^{-18 *} \\
-338 \times 10^{-18 *}\end{array}$ & & $-0.009^{*}$ & & $0 \cap 34 * *$ & \\
\hline NEGSP $(-4)$ & & & & & $1.06 \times 10^{-5}$ & & & $4.21 \times 10^{-18}$ & $1.05 \times 10^{-18}$ & & & & $\begin{array}{l}0.057 \\
-0.069\end{array}$ & \\
\hline C & $0.027 *$ & -0.002 & 0.074 * & 0.089 & $-0.004 *$ & 0.986 & -0.4378 & $-6.94 \times 10^{-18 *}$ & $1.98 \times 10^{-16}$ & 0.001 * & 0.364 & 0.013 & 0.123 * & 0.035 \\
\hline F STAT & 31.236 & 8.539 & 6.422 & 6.980 & 3.122 & 4.987 & 8.986 & $4.28 \times 10^{19}$ & $4.2 \times 10^{19}$ & 1.198 & 25.763 & 4.106 & 5.650 & 5.852 \\
\hline F prob & 0.000 & 0.000 & 0.000 & 0.000 & 0.003 & 0.000 & 0.000 & 0.000 & 0.000 & 0.309 & 0.000 & 0.000 & 0.000 & 0.000 \\
\hline
\end{tabular}

$10 \%$ level is identified by * and at the $5 \%$ level by ** and $1 \%$ by $* * *$.

Table 6. NARDL dependent variable: stock price.

\begin{tabular}{|c|c|c|c|c|c|c|c|c|c|c|c|c|c|c|}
\hline Variables & Brazil & China & India & Mexico & S-Africa & Pakistan & Canada & France & Germany & Italy & Japan & UK & USA & Russia \\
\hline $\mathrm{SP}(-1)$ & $-0.088^{* * *}$ & $-0.094 * *$ & $-0.010^{* *}$ & $-0.008 * *$ & $-0.513 * *$ & $-0.008 * *$ & -0.004 ** & $-0.002 * *$ & -0.003 ** & $-0.002 * *$ & $-0.002 * *$ & $-0.004 * *$ & $-0.003 * *$ & $-0.001^{* *}$ \\
\hline DSP(-1) & -0.074 * & $0.048^{*}$ & $0.052 *$ & $0.185 *$ & $0.205^{* * *}$ & & & -0.037 * & & -0.028 * & $-0.032 *$ & $-0.036 *$ & $-0.072 *$ & \\
\hline DSP(-2) & & $-0.050 *$ & & -0.108 & $0.054 *$ & & $-0.032 *$ & -0.032 & & & & $-0.049 *$ & -0.033 & \\
\hline DSP $(-3)$ & -0.046 & 0.050 * & & -0.110 * & $0.265^{* * *}$ & 0.027 & & $-0.047 *$ & & & $-0.025 *$ & $-0.048 *$ & & \\
\hline DSP(-4) & & 0.062 & & & $0.084^{* * *}$ & -0.038 & 0.024 & & & $0.046 *$ & & & & -0.026 \\
\hline $\begin{array}{c}\text { POSEX } \\
\text { POSER(-1) }\end{array}$ & $\begin{array}{l}-5829.44^{* *} \\
342.064\end{array}$ & $-0.374 * *$ & $-13.256^{* *}$ & $-3.127 * *$ & $0.222 *$ & $-2.50^{* *}$ & $-175.88^{* *}$ & 1.356 ** & $146.684^{* *}$ & $26.767 * *$ & $0.464^{* *}$ & $2.149^{* *}$ & $-29.03 * *$ & $0.038^{* *}$ \\
\hline POSER(-2) & 342.064 & & $48.125 *$ & & & & -558.74 & & -638.07 & & & 263.861 & $24.412^{*}$ & \\
\hline POSER(-3) & & & -36.301 & & & & 452.10 * & & & & & & -19.49 & \\
\hline POSER(-4) & & & & & & & 256.49 & & 484.09 & & & & $24.639 *$ & \\
\hline NEGER & $-4323.8^{*}$ & $-0.549 * *$ & $-1.854^{* *}$ & 45.690 ** & $0.249^{* *}$ & $-3.199 * *$ & 27.201 ** & 1260.120 ** & $-120.65 *$ & 29.18 & $-6.96 * *$ & $957.84^{* * *}$ & $-8.38^{* *}$ & 0.719 * \\
\hline NEGER(-1) & 330.85 * & & & & & & & $128.8 * * *$ & & & 20.222 & $-1220.211^{* * *}$ & 21.020 & \\
\hline NEGER(-2) & & & & -226.374 & & & $466.726^{*}$ & & 693.448 & & $-15.77^{*}$ & & -17.991 & \\
\hline NEGER(-3) & & & & & & & -520.97 & & $-582.56 *$ & & 17.227 & & 24.68 & \\
\hline NEGER(-4) & & & & $177.02 *$ & & & & & & & -14.371 & & -18.985 & \\
\hline C & $62.146 *$ & $4.150 *$ & $19.039 *$ & 154.42 & $25,840.8$ ** & $7.531^{* *}$ & $37.821 * *$ & 12.637 ** & $14.665 * *$ & $55.993 * *$ & $21.481^{* *}$ & 20.64 ** & $38.316^{*}$ & 1.911 ** \\
\hline F STAT & 25.225 & 7.937 & 4.118 & 37.351 & 207.18 & 6.464 & 2.438 & 9.703 & 2.599 & 3.98 & 3.490 & 9.406 & 6.511 & 1.973 \\
\hline F prob & 0.000 & 0.000 & 0.000 & 0.000 & 0.000 & 0.000 & 0.000 & 0.000 & 0.000 & 0.000 & 0.000 & 0.000 & 0.000 & 0.000 \\
\hline
\end{tabular}




\section{Conclusions}

Currency appreciation or depreciation will affect all companies at the domestic level or at the multinational level. If one country's currency depreciates, it will lead towards the increased cost of imported goods, hence exports will be high at that time because other countries can purchase at low cost, but imports will be low as costs are high.

If firms are export-oriented, then they will have higher sales and enjoy high profits. But if firms are not export-oriented, they may suffer a decline in their profits. If a company benefits from the increase in sales due to currency depreciation, then it will lead to high stock prices and vice versa. Currency appreciation will also lead to changes in stock prices. Results from the sample countries also support the flow-oriented model that exchange rate changes lead to changes in stock price. On the other side, if stock prices change that will also lead towards changes in exchange rates. This is also supported by the results and supports the portfolio approach that emphasizes that changes in stock price also lead towards the changes in exchange rate.

There are many studies on the relationship between currency and equity market and conclusions drawn about short-run and long-run integration. In this study, the main objective is to check the linear short-run relationship measured through linear ARDL and to check the asymmetrical linkages between the currency and equity markets through non-Linear ARDL that either positive and negative changes have different impacts on another variable. Variables are not stationary at level, so non-linearity can be checked. In our study, all variables are stationary at order 1.

Cointegration between these variables are confirmed and they also have a long-run relationship. Short-run effects are checked by VECM and show that there is a short-run relationship between these two variables. To check the asymmetries, either positive or negative changes in stock price had the same impact on exchange rates or were different. Results have shown that there is an asymmetrical relationship between stock price and exchange rate. Results are drawn in each way, from exchange rate to stock price and stock price to exchange rate. This study concentrates on the G8 plus 5 countries sample with Pakistan and draws the inferences from the daily data of 2000-2016.

Results clearly show that there is asymmetrical relationship between the stock price and exchange rate. Further studies can be conducted by adding more countries, more variables and at different periods. This study contributes to policy making such that a country can depreciate their currency to improve their trade balance and must be aware of asymmetrical effects on stock price and exchange rates of their future policies.

Author Contributions: R.L. is the main author of this article as a PhD Scholar under the supervision of R.K. In this article: Conceptualization, R.L. and R.K.; Methodology, R.L.; Software, R.L.; Validation, R.L. and R.K.; Formal Analysis, R.L.; Investigation, R.L.; Resources, R.L.; Data Curation, R.L. Writing-Original Draft Preparation, R.L. Writing-Review \& Editing, R.L.; Visualization, R.L.; Supervision, R.K.; Project Administration, R.K.; Funding Acquisition, R.L.

Funding: This research received no external funding.

Conflicts of Interest: The authors declare no conflict of interest. 
Appendix A
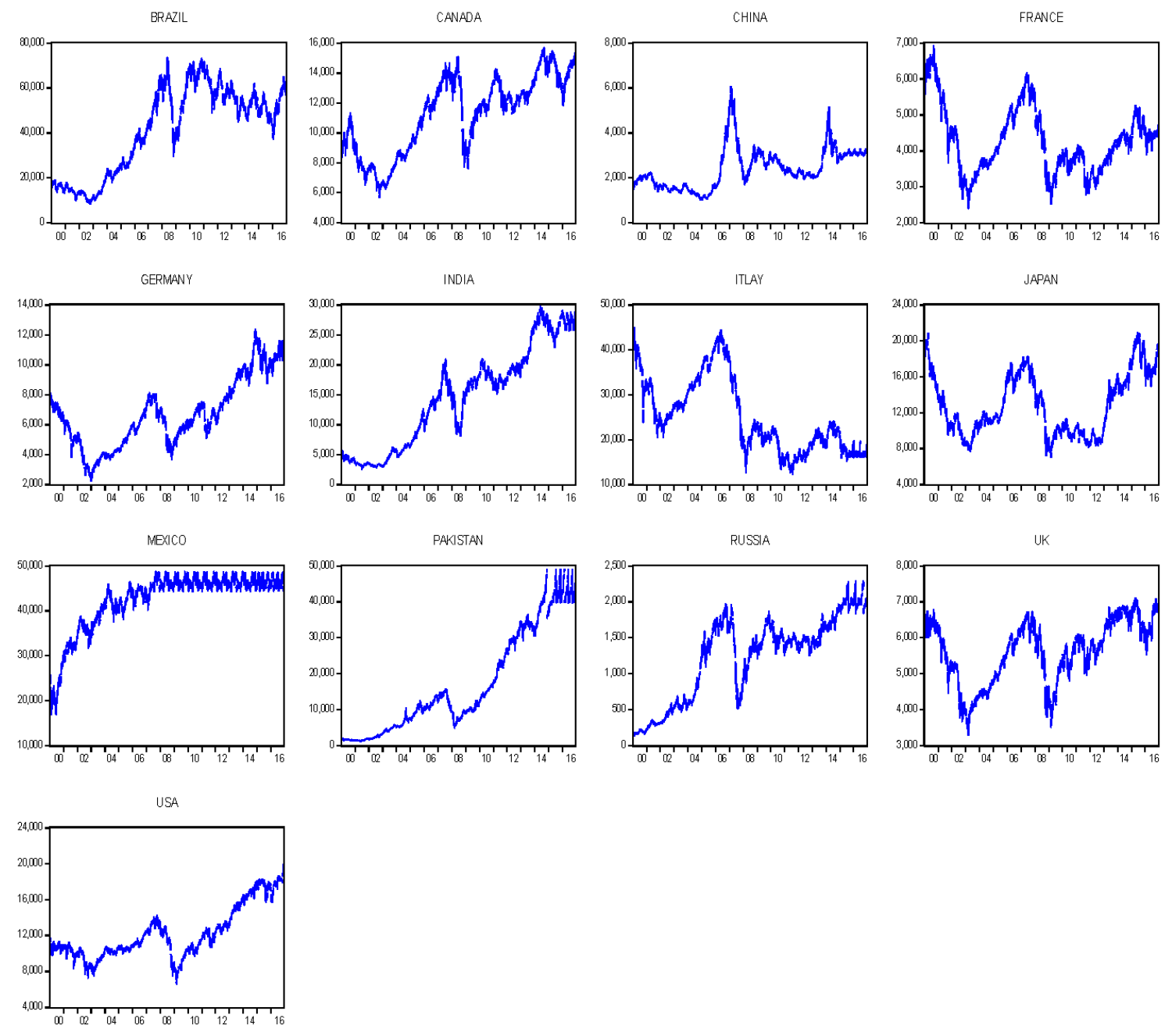

Figure A1. Graph of stock indices of sample countries. 


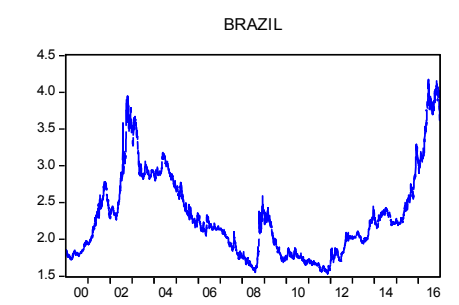

GERMANY

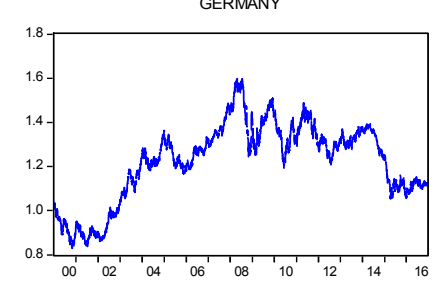

MEXXCO
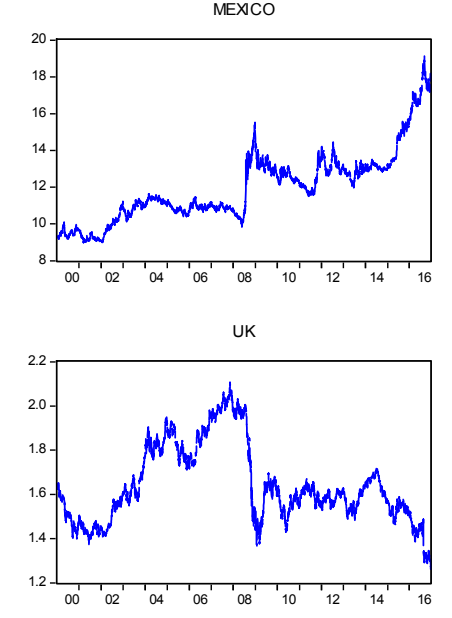

CANADA

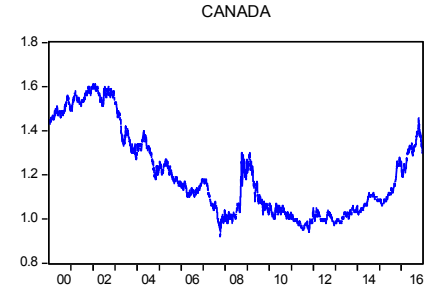

INDIA

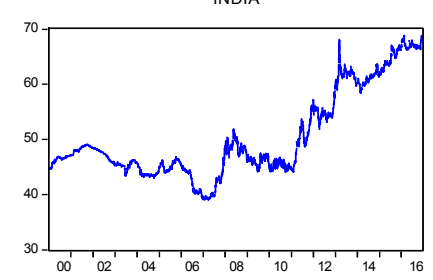

PAKISTAN

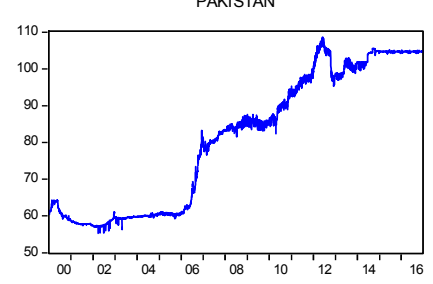

USA

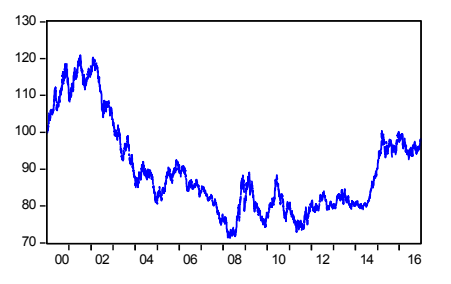

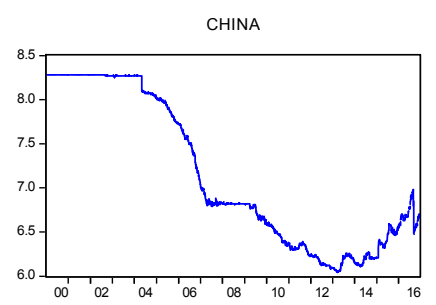

ITLAY

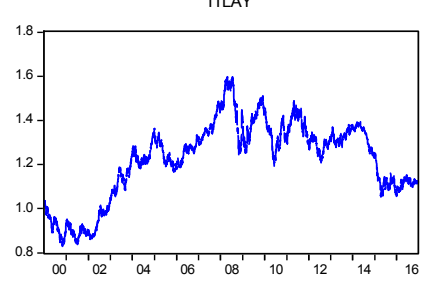

RUSSIA

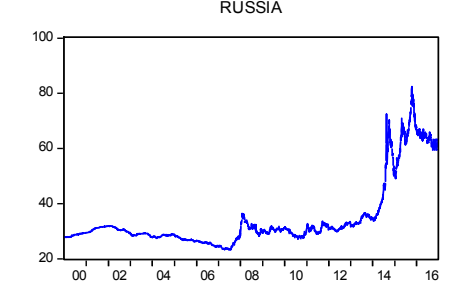

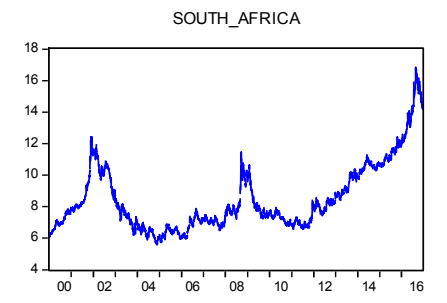

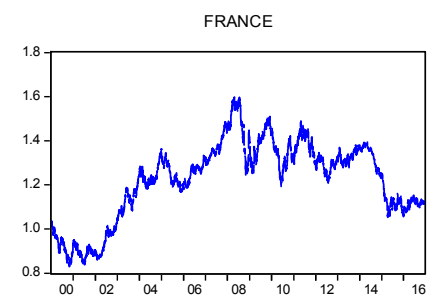

JAPAN

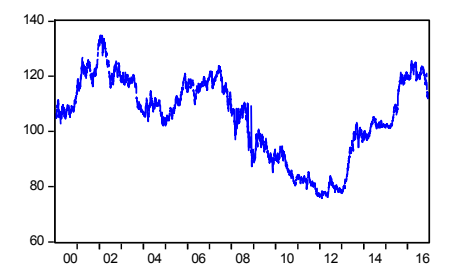

SOUTH_AFRICA

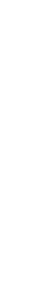

Figure A2. Graph of exchange rates of sample countries. 


\section{References}

Abdalla, Issam S. A., and Victor Murinde. 1997. Exchange rate and stock price interactions in emerging financial markets: Evidence on India, Korea, Pakistan and the Philippines. Applied Financial Economics 7: 25-35. [CrossRef]

Aggarwal, R. 1981. Exchange rates and stock prices: A study of the U.S. capital markets under floating exchange rates. Akron Business and Economic Review 12: 7-12.

Alagidede, Paul, Theodore Panagiotidis, and Xu Zhang. 2011. Causal relationship between stock prices and exchange rates. The Journal of International Trade \& Economic Development 20: 67-86.

Bahmani-Oskooee, Mohsen, and Sujata Saha. 2015. On the relation between stock prices and exchange rates: A review article. Journal of Economic Studies 42: 707-32. [CrossRef]

Bahmani-Oskooee, Mohsen, and Sujata Saha. 2016. Do exchange rate changes have symmetric or asymmetric effects on stock prices? Global Finance Journal 31: 57-72. [CrossRef]

Bahmani-Oskooee, Mohsen, and Sujata Saha. 2017. On the relation between exchange rates and stock prices: A non-linear ARDL approach and asymmetry analysis. Journal of Economics and Finance 42: 112-37. [CrossRef]

Bahmani-Oskooee, Mohsen, and Ahmad Sohrabian. 1992. Stock prices and the effective exchange rate of the dollar. Applied Economics 24: 459-64. [CrossRef]

Banerjee, Anindya, Juan Dolado, and Ricardo Mestre. 1998. Error-correction mechanism tests for cointegration in a single-equation framework. Journal of Time Series Analysis 19: 267-83. [CrossRef]

Boonyanam, Nararuk. 2014. Relationship of stock price and monetary variables of Asian small open emerging economy: Evidence from Thailand. International Journal of Financial Research 5: 52. [CrossRef]

Branson, William H. 1983. A Model of Exchange-Rate Determination with Policy Reaction: Evidence from Monthly Data. Cambridge: The National Bureau of Economic Research. [CrossRef]

Buberkoku, Onder. 2013. The Relationship between Stock Prices and Exchange Rates Evidence from Developed and Developing Countries. Istanbul Stock Exchange Review 13: 1-16.

Caporale, Guglielmo Maria, John Hunter, and Faek Menla Ali. 2014. On the linkages between stock prices and exchange rates: Evidence from the banking crisis of 2007-2010. International Review of Financial Analysis 33: 87-103. [CrossRef]

Chortareas, Georgios, Ying Jiang, and John C. Nankervis. 2011. Forecasting exchange rate volatility using high-frequency data: Is the euro different? International Journal of Forecasting 27: 1089-107. [CrossRef]

Dickey, David A., and Wayne A. Fuller. 1979. Distribution of the estimators for autoregressive time series with a unit root. Journal of the American Statistical Association 74: 427-31.

Dornbusch, Rüdiger, William H. Branson, Marina V. N. Whitman, Peter Kenen, Hendrik Houthakker, Robert E. Hall, Robert Lawrence, George Perry, William Fellner, William Brainard, and et al. 1980. Exchange rate economics: Where do we stand? Brookings Papers on Economic Activity 1: 143-205. [CrossRef]

Eita, Joel Hinaunye. 2012. Modelling macroeconomic determinants of stock market prices: Evidence from Namibia. Journal of Applied Business Research (JABR) 28: 871-84. [CrossRef]

Engle, Robert F., and C.W.J. Granger. 1987. Co-integration and error correction: Representation, estimation, and testing. Econometrica: Journal of the Econometric Society 55: 251-76. [CrossRef]

Frankel, Tamar. 1983. Fiduciary law. California Law Review 71: 795. [CrossRef]

Granger, Clive W. J., Bwo-Nung Huangb, and Chin-Wei Yang. 2000. A bivariate causality between stock prices and exchange rates: Evidence from recent Asianflu. The Quarterly Review of Economics and Finance 40: 337-54. [CrossRef]

Groenewold, Nicolaas, and James E. H. Paterson. 2013. Stock prices and exchange rates in Australia: Are commodity prices the missing link? Australian Economic Papers 52: 159-70. [CrossRef]

Harjito, Agus D., and Carl B. McGowan. 2011. Stock price and exchange rate causality: The case of four asean countries. Southwestern Economic Review 34: 103-14.

Inegbedion, Henry Egbezien. 2012. Macroeconomic determinants of stock price changes: Empirical evidence from Nigeria. Indian Journal of Finance 6: 19-23.

Ismail, Mohd Tahir, and Zaidi Bin Isa. 2009. Modeling the interactions of stock price and exchange rate in Malaysia. The Singapore Economic Review 54: 605-19. [CrossRef]

Jorion, Philippe. 1990. The exchange-rate exposure of US multinationals. Journal of Business 63: 331-45. [CrossRef] 
Khan, Faisal, Saqib Muneer, and Anuar M. Ahmad. 2013. Relationship between stock prices and economic variables: Sectoral analysis. Actual Problems of Economics 143: 544-53.

Kollias, Christos, Nikolaos Mylonidis, and Suzanna-Maria Paleologou. 2012. The nexus between exchange rates and stock markets: Evidence from the euro-dollar rate and composite European stock indices using rolling analysis. Journal of Economics and Finance 36: 136-47. [CrossRef]

Kutty, Gopalan. 2010. The Relationship between exchange rates and stock prices: The case of Mexico. North American Journal of Finance and Banking Research 4: 1-12.

Lean, Hooi Hooi, Paresh Narayan, and Russell Smyth. 2011. Exchange rate and stock prices interaction in major Asian markets: Evidence for individual countries and panels allowing for structural breaks. The Singapore Economic Review 56: 255-77. [CrossRef]

Lee, Chia-Hao, Shuh-Chyi Doong, and Pei-I. Chou. 2011. Dynamic correlation between stock prices and exchange rates. Applied Financial Economics 21: 789-800. [CrossRef]

Lin, Chien-Hsiu. 2012. The co-movement between exchange rates and stock prices in the Asian emerging markets. International Review of Economics \& Finance 22: 161-72.

Ma, Christopher K., and G. Wenchi Kao. 1990. On exchange rate changes and stock price reactions. Journal of Business Finance \& Accounting 17: 441-49.

Mookerjee, Rajen, and Qiao Yu. 1997. Macroeconomic variables and stock prices in a small open economy: The case of Singapore. Pacific-Basin Finance Journal 5: 377-88. [CrossRef]

Moore, Tomoe, and Ping Wang. 2014. Dynamic linkage between real exchange rates and stock prices: Evidence from developed and emerging Asian markets. International Review of Economics E Finance 29: 1-11.

Obben, James, Andrew Pech, and Shamim Shakur. 2006. Analysis of the relationship between the share market performance and exchange rates in New Zealand: A cointegrating VAR approach. New Zealand Economic Papers 40: 147-80. [CrossRef]

Pan, Ming-Shiun, Robert Chi-Wing Fok, and Y. Angela Liu. 2007. Dynamic linkages between exchange rates and stock prices: Evidence from East Asian markets. International Review of Economics \& Finance 16: 503-20.

Parsva, Pardis, and Hooi Hooi Lean. 2011. The analysis of relationship between stock prices and exchange rates: Evidence from six Middle Eastern financial markets. International Research Journal of Finance and Economics 66: 157-71.

Pesaran, M. Hashem, Yongcheol Shin, and Richard J. Smith. 2001. Bounds testing approaches to the analysis of level relationships. Journal of Applied Econometrics 16: 289-326. [CrossRef]

Phillips, Peter C. B., and Pierre Perron. 1988. Testing for a unit root in time series regression. Biometrika 75: 335-46. [CrossRef]

Phylaktis, Kate, and Fabiola Ravazzolo. 2005. Stock prices and exchange rate dynamics. Journal of International Money and Finance 24: 1031-53. [CrossRef]

Rahman, Md Lutfur, and Jashim Uddin. 2009. Dynamic relationship between stock prices and exchange rates: Evidence from three South Asian countries. International Business Research 2: 167. [CrossRef]

Richards, John Simpson, and John Evans. 2009. The interaction between exchange rates and stock prices: An Australian context. International Journal of Economics and Finance 1: 3-23. [CrossRef]

Shin, Yongcheol, Byungchul Yu, and Matthew Greenwood-Nimmo. 2014. Modelling asymmetric cointegration and dynamic multipliers in a nonlinear ARDL framework. In Festschrift in Honor of Peter Schmidt. New York: Springer, pp. 281-314.

Smyth, Russell, and Nandha. 2003. Bivariate causality between exchange rates and stock prices in South Asia. Applied Economics Letters 10: 699-704. [CrossRef]

Soenen, Luc A., and Elizabeth S. Hennigar. 1988. An analysis of exchange-rates and stock-prices-the united-states experience between 1980 and 1986. Akron Business and Economic Review 19: 7-16.

Solnik, Bruno. 1987. Using financial prices to test exchange rate models: A note. The Journal of Finance 42: 141-49. [CrossRef]

Tian, Gary Gang, and Shiguang Ma. 2010. The relationship between stock returns and the foreign exchange rate: the ARDL approach. Journal of the Asia Pacific Economy 15: 490-508. [CrossRef]

Tsagkanos, Athanasios, and Costas Siriopoulos. 2013. A long-run relationship between stock price index and exchange rate: A structural nonparametric cointegrating regression approach. Journal of International Financial Markets, Institutions and Money 25: 106-18. [CrossRef] 
Tsai, I-Chun. 2012. The relationship between stock price index and exchange rate in Asian markets: A quantile regression approach. Journal of International Financial Markets, Institutions and Money 22: 609-21. [CrossRef]

Tuncer, Ismail, and Tuncay Turan Turaboglu. 2014. Relationship between stock prices and economic activity in Turkish economy. Actual Problems of Economics 152: 111-21.

Unlu, Ulas. 2013. Oil price, exchange rate and stock market in ASEAN-5 countries. The Empirical Economics Letter: A Monthly International Journal of Economics 12: 551-57.

Wickremasinghe, Guneratne B. 2012. Stock prices and exchange rates in Sri Lanka: Some empirical evidence. Investment Management \& Financial Innovations 9: 8-14.

Yang, Zheng, Anthony H. Tu, and Yong Zeng. 2014. Dynamic linkages between Asian stock prices and exchange rates: New evidence from causality in quantiles. Applied Economics 46: 1184-201. [CrossRef]

Yau, Hwey-Yun, and Chien-Chung Nieh. 2006. Interrelationships among stock prices of Taiwan and Japan and NTD/Yen exchange rate. Journal of Asian Economics 17: 535-52. [CrossRef]

Yau, Hwey-Yun, and Chien-Chung Nieh. 2009. Testing for cointegration with threshold effect between stock prices and exchange rates in Japan and Taiwan. Japan and the World Economy 21: 292-300. [CrossRef]

Zhao, Hua. 2010. Dynamic relationship between exchange rate and stock price: Evidence from China. Research in International Business and Finance 24: 103-12. [CrossRef]

(C) 2018 by the authors. Licensee MDPI, Basel, Switzerland. This article is an open access article distributed under the terms and conditions of the Creative Commons Attribution (CC BY) license (http://creativecommons.org/licenses/by/4.0/). 